\title{
Antibiotic therapy for pediatric dental patients
}

\author{
Alexandrina Muntean ${ }^{1}$, Irina Lupse ${ }^{1}$, Ioana-Andreea Chis ${ }^{2}$, Mircea Ghergie ${ }^{3}$, \\ Lavinia Luminita Voina', Cristian Olteanu ${ }^{3}$, Alexandra Roman ${ }^{4}$, Mariana Pacurar ${ }^{5}$ \\ ${ }^{1}$ Department of Paediatric Dentistry, "Iuliu Hatieganu” University of Medicine and Pharmacy, Cluj Napoca, Romania \\ 2Paediatric Dentistry, Cluj County Clinical Hospital, Romania \\ ${ }^{3}$ Department of Orthodontics and Dentofacial Orthopedics, \\ "Iuliu Hatieganu" University of Medicine and Pharmacy, Cluj Napoca, Romania \\ ${ }^{4}$ Department of Periodontology, "Iuliu Hatieganu" University of Medicine and Pharmacy, Cluj Napoca, Romania \\ 5"G.E. Palade" University of Medicine, Pharmacy, Science, and Technology, Tg. Mures, Romania
}

\begin{abstract}
The oral pathologies in paediatric patients frequently require the recommendation of adjuvant medication. A lack of knowledge regarding well-defined prescription protocols has been observed in every day practice. The aim of this study was to revise and update the prescription of antibiotics according to the latest guidelines.

We performed electronic research of selected databases: PubMed, Google Scholar, AAPD, from 2010-2020 in order to identify the most frequent antibiotics used in paediatric dentistry.

The antibiotic resistance of bacteria, as well as the side effects that follow the prescription of antibiotics are reported to be in a continuous growth as a result of inadequate use. Prescription of medication, especially antibiotics in paediatric dentistry, must analyze both short and long-term side-effects.
\end{abstract}

Keywords: antibiotics, medication, prescription, pediatric dentistry

\section{BACKGROUND}

\section{Antimicrobial substances}

Most of the dental procedures within pediatric dentistry do not represent a risk of bacteremia among clinically healthy patients. The medication in dentistry is mostly prescribed to patients with the purpose of reducing pain and treating bacterial, fungal, viral infections [1,2].

Antimicrobial substances degrade or suppress the growth or the multiplication of microorganisms (bacteria, viruses, fungi, parasites). These substances present a selective toxicity - a lower concentration destroys the microorganisms without causing detriment to the host cells - this ability allows their safe usage [1].
A microorganism's susceptibility to an antibiotic is based on its minimum necessary concentration for that microorganism to stop its dividing not to be destroyed [1].

Antibiotic prophylaxis is an aid for pedodontic treatments in those situations where there's a risk of bacteremia. This prophylaxis implie the administration of antibiotics before the potentially infectious dental therapy begins [1].

Multiple factors have to be taken into consideration when prescribing antibiotics, such as: the host's (patient's) immune defence mechanisms, the severity and the localisation of the infection, as well as the incriminated type of pathogen $[3,4]$.

An effective antibiotic therapy consists of identifying the pathogen through a bacterial culture or 
a serological test. In the dental practice, this microbiological testing is rarely done [1] It is, however, indicated post-operative, in recurrent, mistreated or incompletely treated infections, in the treatment of periodontal disease, in immunosuppressed patients or when an osteomyelitis is suspected [1]. From a microbiological perspective, in $50 \%$ of cases Streptococcus viridians is identified as a bacterial species [5].

Due to the fact that the dental pulp has a terminal type of blood circulation, in case of an infection the inflammation and the immunity are compromised, thus making the root canal a unique bacterial environment $[3,4,6]$.

\section{The spectrum of an antibiotic}

It refers to the microorganism species it has an effect on. The antibiotics with a narrow spectrum have an effect on a limited group of microorganisms, whilst those with a broad spectrum have an impact on Gram positive organisms, as well as on a relatively large number of Gram-negative organisms.

\section{Bacteriostatic versus bactericidal}

Whilst the bacteriostatic limits the spread of the pathogen throughout the body by stopping its growth and diving, the bactericidal determines the irreversible destruction of the cells. In the case of bacteriostatic antibiotics, the immune system is let to attack, immobilize and destroy the pathogens. The effects of the bacteriostatic are reversible in the lack of an ulterior immune response, which, therefore, can make the infection reoccur $[1,2]$.

Thus, the action of bactericidal antibiotics is preferred in most of the cases, including oral infections, due to the independent way of action - such as immunocompromised patients [1].

\section{Dosage in children}

The dosage in children has to be individualized according to the child's age and bodyweight. A general calculation formula is:

Adult dosage $\mathrm{x}$ child weight $\mathrm{x} \mathrm{K} /$ adult weight where $\mathrm{K}$ stands for a correction coefficient that has different values in regards to the patient's age:

- $\mathrm{K}=2$ for children under one year;

- $\mathrm{K}=1,5$ for children with ages between 1-12 years;
- $\mathrm{K}=1,25$ for children with ages between 12-18 years [5]

In the event that the child's body weight is unknown, the dosage can be calculated regarding its age, starting from the adult's specific dosage:

- 1-3 years old $=1 / 6$ of the adult dosage;

- 3-7 years old $=1 / 3$ of the adult dosage;

- 7-12 years $=1 / 2$ of the adult dosage;

- 12-17 years $=2 / 3$ of the adult dosage [5]

A correlation between the patient's age, the objectives of the pharmacotherapy and the used forms of medication is required.

Different nations, globally, have published their own protocols in order to ensure an efficient and safe usage of medications, both prophylactically and therapeutically in numerous pathologies - after a correct assessment of the systemic spread of the infection, as well as an assessment of the patient's risk factors [8].

\section{METHODS}

We performed electronic research of databases: PubMed, Google Scholar, AAPD. We've searched for articles (review, cross-sectional studies, clinical studies, laboratory studies, in English and published / revised in the last 10 years (2010-2020).

The keywords used to search the articles were: antibiotic(s), p(a)ediatric dentistry, antibacterial, antimicrobial and resistance.

Out of a total of 135 articles found, 46 met the criteria of our chosen topic. The other studies were rejected because they lacked relevance and/or specificity in regards to this article's theme. Some of the criteria that wasn't met is related to the language the articles were written in and the date they were published at. Two independent reviewers analysed the articles and made the selection according to the mentioned criteria.

\section{MOST USED ANTIBIOTICS}

Dar-Odeh et al. note that in pediatric dentistry amoxicillin is the most frequently prescribed antibiotic, with an indication of administration of 5 days. In case of a penicillin and/or cephalosporins allergy, clindamycin, azithromycin and metronidazole have been the most frequent second choice, due to their broad spectrum of action $[5,7,8,9]$ Isla et al. reported a notable efficacy of Metronidazole 
only on anaerobe species [10]. Easton et al. have proved the superiority of amoxicillin/clavulanic acid over azithromycin, regarding the provided clinical and bacteriologic response [11]. Hong et al. indicate that an exposure of the child to amoxicillin can be the cause of enamel developmental defects, both in the first primary molars, as well as in the central maxillary incisors [12]. Nevertheless, amoxicillin is considered to be the safest and most efficient antibiotic prescribed to children $[3,9,11]$. According to Isla et al., a minimum total dose of $1 \mathrm{~g}$ /day of amoxicillin: potassium clavulanate has proved to be efficient on the most frequent bacteria that cause odontogenic infections [10].

Having both a bactericidal and a bacteriostatic action and being well distributed among all the fluids in the organism (except for spinal fluid), Clindamycin penetrates bones and abscesses. Furthermore, Nowak et al. mentions that, due to its very good activity against oral pathogens, Clindamycin is the default antibiotic for severe oral infections [1] (table 1).

\section{ANTIBIOTIC PROPHYLAXIS}

Indications for antibiotic prophylaxis are: fever over $37.5^{\circ} \mathrm{C}$ in the last 24 hours (this indicates a systemic response to an infection), trismus, immunocompromised patients/pathological states, wounds/fractures/open lesions, contaminated with extrinsical agents, in avulsed teeth with open or closed apex (as an aiding therapy), in patients with an aggressive form of periodontal disease (combined with a local treatment), in pericoronitis $[1,3,7,13,18,19,20]$.

In the bacterial endocarditis antibiotic prophylaxis in recommended cardiovascular pathologies, according with patient risk: major risk (valvular prosthesis, bacterial endocarditis in past medical records), medium risk (uncorrected valvulopathy,

TABLE 1. Dosage of antibiotics in paediatric dentistry

\begin{tabular}{|c|c|c|c|c|}
\hline Author & Antibiotic & Children under 12 years & $\begin{array}{l}\text { Children over } 12 \text { years/ } \\
\text { Adolescents }\end{array}$ & $\begin{array}{c}\text { Maximum } \\
\begin{array}{c}\text { recommended } \\
\text { dose }\end{array} \\
\end{array}$ \\
\hline $\begin{array}{l}\text { Skoog Ståhlgren et } \\
\text { al. (2019) }\end{array}$ & $\begin{array}{c}\text { Penicillins } \\
\text { G(intramuscular/ } \\
\text { intravenous) and V } \\
\text { (per os) }\end{array}$ & $20-50$ mg/kg/day [14] & $\begin{array}{c}1-2 \mathrm{~g} / \text { day, in } 3 \text { or } 4 \text { doses per } \\
\text { day }[14]\end{array}$ & 3 g/day [14] \\
\hline $\begin{array}{l}\text { AAPD } \\
(2019)\end{array}$ & Amoxicillin & $20-40$ mg/kg/day [13] & $\begin{array}{c}250-500 \mathrm{mg} \text {, in } 3 \text { doses per day } \\
{[13]}\end{array}$ & 2-3 g/day [13] \\
\hline $\begin{array}{c}\text { AAPD } \\
\text { (2019), Easton J } \\
\text { et al. (2003) }\end{array}$ & $\begin{array}{c}\text { Amoxicillin }+ \\
\text { potassium clavulanate }\end{array}$ & $20-40 \mathrm{mg} / \mathrm{kg} / \mathrm{day}[11,13]$ & $\begin{array}{c}250-300 \mathrm{mg}, 3 \text { times a day or } \\
875 \mathrm{mg} \text { twice a day [13] }\end{array}$ & 2 g/day [13] \\
\hline $\begin{array}{c}\text { AAPD } \\
\text { (2019), Bakheit AHH } \\
\text { et al. (2014) }\end{array}$ & Azithromycin & $\begin{array}{c}\text { just one per day: in children } \\
\text { older than } 6 \text { months }=10 \mathrm{mg} / \\
\mathrm{kg} / \text { day on the } 1 \mathrm{st} \text { day, } \\
\text { then } 5 \mathrm{mg} / \mathrm{kg} / \text { day in days } 2-5 \\
{[13]}\end{array}$ & $\begin{array}{c}\text { In adults and/or adolescents } \\
\text { older than } 16=500 \mathrm{mg} / \text { day on } \\
\text { the } 1 \text { st day, then } 250 \mathrm{mg} / \text { day } \\
\text { in days } 2-5 . \text { In adults }=500 \mathrm{mg} / \\
\text { day for } 3 \text { days }[13,15]\end{array}$ & 500 mg/day [13] \\
\hline $\begin{array}{l}\text { AAPD } \\
(2019)\end{array}$ & $\begin{array}{l}\text { Cephalosporins } \\
\text { (Cefuroxime) }\end{array}$ & $\begin{array}{c}25-50 \mathrm{mg} / \mathrm{kg} / \text { day } \\
25-100 \mathrm{mg} / \mathrm{kg} / \text { day [13] }\end{array}$ & $\begin{array}{c}250-1,000 \mathrm{mg}, 4 \text { times a day } \\
{[13]}\end{array}$ & $\begin{array}{c}4 \mathrm{~g} / \text { day, for a total } \\
\text { period of } 10 \text { days } \\
{[13]}\end{array}$ \\
\hline $\begin{array}{c}\text { AAPD } \\
\text { (2019), Smith MJ } \\
\text { et al. (2017) }\end{array}$ & Clindamycin & $\begin{array}{c}10-35 \mathrm{mg} / \mathrm{kg} / \text { day }[16] / 8-20 \\
\mathrm{mg} / \mathrm{kg} / \text { day [13] }\end{array}$ & $\begin{array}{c}600-1,800 \mathrm{mg} 3 \text { times a day } \\
{[13]}\end{array}$ & $4-8 \mathrm{~g} /$ day [13] \\
\hline $\begin{array}{c}\text { AAPD } \\
\text { (2019), Wilcox MH } \\
\text { et al. (2017) }\end{array}$ & $\begin{array}{l}\text { Cephalosporins } \\
\text { (Cefuroxime) }\end{array}$ & $\begin{array}{c}25-50 \mathrm{mg} / \mathrm{kg} / \text { day [6] / 25-100 } \\
\mathrm{mg} / \mathrm{kg} / \text { day [13] }\end{array}$ & $\begin{array}{c}250-1,000 \mathrm{mg}, 4 \text { times a day } \\
{[13,15]}\end{array}$ & $\begin{array}{c}4 \mathrm{~g} / \text { day, for a total } \\
\text { period of } 10 \text { days } \\
{[13]}\end{array}$ \\
\hline $\begin{array}{c}\text { AAPD } \\
\text { (2019), McFarland } \\
\text { LV et al. (2010) }\end{array}$ & Metronidazole & $\begin{array}{c}20-40 \mathrm{mg} / \mathrm{kg} / \text { day, fragmented } \\
\text { every } 6 \text { hours }[13,18]\end{array}$ & $500 \mathrm{mg}, 3$ times a day $[18,19]$ & 4 g/day [13] \\
\hline $\begin{array}{c}\text { Vicente D, } \\
\text { Pérez-Trallero E } \\
\text { (2010) }\end{array}$ & Tetracycline & $\begin{array}{l}\text { In children under } 8 \text { years of } \\
\text { age, the administration is } \\
\text { forbidden. } \\
\text { Children over } 8 \text { years }=25-50 \\
\text { mg/kg/day. [17] }\end{array}$ & 250-500 mg, 3-4 times a day & 2 g/day \\
\hline
\end{tabular}


uncorrected septal defects), low risk (corrected cardiac malformations, mitral valve prolapses without regurgitation, acute articular rheumatism in the past (without valvular sequelae)) [20] (table 2).

TABLE 2. Dosage of antibiotics in bacterial endocarditis prophylaxis in paediatric dentistry

\begin{tabular}{|c|c|c|}
\hline Author & Antibiotic & $\begin{array}{l}\text { Bacterial endocarditis } \\
\text { prophylaxis }\end{array}$ \\
\hline $\begin{array}{c}\text { AAPD } \\
(2019), \\
\text { Bragg L et al. } \\
(2014)\end{array}$ & Amoxicillin & $\begin{array}{l}50 \mathrm{mg} / \mathrm{kg} \text {, with a maximum } \\
\text { of } 2 \mathrm{~g}, 30-60 \text { minutes before } \\
\text { the dental procedure }[13,22]\end{array}$ \\
\hline $\begin{array}{c}\text { AAPD } \\
\text { (2019), } \\
\text { Bragg L et al. } \\
(2014)\end{array}$ & Azithromycin & $\begin{array}{c}15 \mathrm{mg} / \mathrm{kg} \text {, with a maximum } \\
\text { of } 500 \mathrm{mg}, 30-60 \text { minutes } \\
\text { before the dental procedure } \\
{[13,22]}\end{array}$ \\
\hline $\begin{array}{l}\text { AAPD } \\
(2019)\end{array}$ & $\begin{array}{c}\text { Cephalosporins } \\
\text { (Cefuroxime) }\end{array}$ & $\begin{array}{l}50 \mathrm{mg} / \mathrm{kg} \text {, with a maximum } \\
\text { of } 2 \mathrm{~g}, 30-60 \text { minutes before } \\
\text { the dental procedure [13] }\end{array}$ \\
\hline $\begin{array}{c}\text { AAPD } \\
\text { (2019), } \\
\text { Bragg L et al. } \\
(2014)\end{array}$ & Clindamycin & $\begin{array}{c}\text { Orally: } 20 \mathrm{mg} / \mathrm{kg} \text { (maximum } \\
600 \mathrm{mg} \text { ) with } 30-60 \text { minutes } \\
\text { before the dental procedure; } \\
\text { Intramuscular or intravenous: } \\
15 \mathrm{mg} / \mathrm{kg} \text { (maximum } 600 \\
\mathrm{mg} \text { ), administered } 30-60 \\
\text { minutes before the dental } \\
\text { procedure; }[13,22]\end{array}$ \\
\hline
\end{tabular}

Contraindications for antibiotic prophylaxis are: pain, oedema, erythema, purulent collection, primary teeth luxations, dry alveolitis, plaque-induced gingivitis, eruption gingivitis, pubertal gingivitis, gingivitis as a side effect of oral breathing, primary herpetic gingivostomatitis, viral diseases, at the request of the patients/caregivers $[3,7,8,9$, $13,9,21]$.

\section{INADEQUATE USE OF ANTIBIOTICS}

Several studies show a tendency of over-prescribing antibiotics without a clinical indication, in numerous dental pathologies such as irreversible pulpitis, dental abscess or even for pain management $[1,11,24,28,29]$. Goel et al. emphasize the importance of four criteria in antibiotic prescription: choosing the appropriate antibiotic, the right dosage, the precise period of administration and choosing, as much as possible, the antimicrobial substance aimed to the pathogen [3]. The administration of antibiotics requires a good comprehension and a correct diagnosis, taking into account their beneficial effects in comparison with the immediate or late side effects [7].
These unjustified prescriptions are reported to be constantly increasing from year to year [24].

According to a study conducted in UK on 568 patients, Cope et al. reported that more than half of antibiotics $(65.6 \%)$ were prescribed in situations where there is no sign of infection, and $70.6 \%$ were prescribed without considering an operative intervention. Only 19\% of antibiotics were prescribed according to the rules in effect [27]. Many dentists prescribe antibiotics, even for the treatment of viral infections (for example: herpes simplex) [23].

Inadequate use of antibiotics, in terms of quantity, timing and duration of treatment, can have important consequences for the child's development. Antibiotics containing sugar (suspensions especially created for easy administration in children - syrups) can cause a number of changes in the oral cavity: the appearance of tooth decay, tooth erosion, and a number of complications, such as pulpal damage (pulpitis) and dental abscess. Proper oral hygiene can prevent the appearance of these pathologies [3] (table 3).

\section{NEGATIVE EFFECTS OF ANTIBIOTICS PROLONGED TREATMENT}

An unnecessary prolonged treatment with antibiotics, for up to 21 days, will reduce the ability of the oral microflora to defend itself against pathogenic microorganisms. Colonies of microorganisms will appear that are not normally found in the oral cavity, leading to the appearance of extremely resistant bacterial or fungal infections [23].

In case of too early exposure to antibiotics, they can also affect the intestinal flora, leading to longterm negative effects, such as obesity, superinfections with Candida albicans, intestinal transit problems [3]. In terms of microbial resistance to antibiotics, there are approximately 1,030 bacteria worldwide, this number providing the genetic material needed for mutations, rearrangements, and gene transfer [34] (table 4).

\section{BACTERIA RESISTANCE}

Prescribing a broad-spectrum antibiotic can significantly damage the microbiome, thus precipitating a superinfection with another pathogen (ex. Candida albicans). Therefore, in medical practice, 
TABLE 3. Antibiotics - indications, contraindications

\begin{tabular}{|c|c|c|c|}
\hline Author & Antibiotic & Indications & Contraindications \\
\hline $\begin{array}{l}\text { Shenoy, E. S et } \\
\text { al. (2019) }\end{array}$ & $\begin{array}{c}\text { Penicillin G } \\
\text { (intramuscular/ } \\
\text { intravenous) and V } \\
\text { (per os) }\end{array}$ & $\begin{array}{c}\text { moderate or severe bacterial infections, with the } \\
\text { sensitive pathogens [29] }\end{array}$ & $\begin{array}{l}\text { hypersensitivity/anterior allergies } \\
\text { (7-10\% of the patients) [29] }\end{array}$ \\
\hline $\begin{array}{l}\text { Abrams EM et } \\
\text { al. (2019) }\end{array}$ & Amoxicillin & $\begin{array}{c}\text { infections with sensitive bacterial species } \\
\text { (acne, chronic bronchitis, syphilis); in patients } \\
\text { allergic to penicillin [30] }\end{array}$ & In patients with penicillin allergy [30] \\
\hline $\begin{array}{l}\text { Easton J et al. } \\
\qquad(2003)\end{array}$ & $\begin{array}{c}\text { Amoxicillin }+ \\
\text { potassium clavulanate }\end{array}$ & $\begin{array}{l}\text { upper respiratory tract infections, otitis, sinusitis, } \\
\text { cutaneous affections [11] }\end{array}$ & $\begin{array}{l}\text { hypersensitivity, in simultaneous } \\
\text { administration of disulfiram, in } \\
\text { patients with penicillin allergies [11] }\end{array}$ \\
\hline $\begin{array}{l}\text { Bakheit AH } \\
\text { et al. (2014) }\end{array}$ & Azithromycin & $\begin{array}{c}\text { in penicillin allergies, in respiratory-tract } \\
\text { infections, otitis media, prophylaxis of group A } \\
\text { streptococcal infection and as prevention therapy } \\
\text { of bacterial endocarditis in patients undergoing } \\
\text { dental procedures who are at high risk for } \\
\text { endocarditis, pertussis, mycobacterial infections } \\
{[25]}\end{array}$ & $\begin{array}{l}\text { liver dysfunctions, hypersensitivity } \\
\qquad[25]\end{array}$ \\
\hline $\begin{array}{l}\text { Campagna JD } \\
\text { et al. (2012) }\end{array}$ & $\begin{array}{l}\text { Cephalosporins } \\
\text { (Cefuroxime) }\end{array}$ & $\begin{array}{c}\text { in patients with penicillin allergies - with advised } \\
\text { skin testing [31] }\end{array}$ & $\begin{array}{l}\text { liver dysfunctions, hypersensitivity } \\
{[31]}\end{array}$ \\
\hline $\begin{array}{l}\text { Smith MJ et al. } \\
\qquad(2017)\end{array}$ & Clindamycin & $\begin{array}{c}\text { infections with sensitive bacterial species } \\
\text { (Streptococcus, Staphylococcus), invasive } \\
\text { infections for which optimal dosing is critical [26] }\end{array}$ & $\begin{array}{l}\text { liver dysfunctions, hypersensitivity } \\
\qquad[26]\end{array}$ \\
\hline $\begin{array}{l}\text { Vicente D et al. } \\
\text { (2010) }\end{array}$ & Metronidazole & $\begin{array}{l}\text { anaerobic bacteria, some microaerophilic bacteria } \\
\text { and protozoa [17] }\end{array}$ & $\begin{array}{l}\text { In patients with liver and/or renal } \\
\text { failure [18] Recent research does } \\
\text { not confirm a clinically relevant } \\
\text { interaction between ethanol and } \\
\text { metronidazole [25] }\end{array}$ \\
\hline $\begin{array}{l}\text { Nowak AJ et al. } \\
\text { (2019). Goel D } \\
\text { et al. (2020) }\end{array}$ & Fluoroquinolones & \multicolumn{2}{|c|}{$\begin{array}{l}\text { Outside of a clear indication after an antibiogram, no indication in dentistry, especially in } \\
\text { the pediatric field }[1,3]\end{array}$} \\
\hline $\begin{array}{l}\text { Vicente D et al. } \\
\text { (2010) }\end{array}$ & Tetracyclin & $\begin{array}{l}\text { Infections with sensitive bacterial species } \\
\text { (acne, chronic bronchitis, syphilis); in patients } \\
\text { allergic to penicillin [17] }\end{array}$ & $\begin{array}{l}\text { In children under } 8 \text { years of age, the } \\
\text { administration is forbidden [17] }\end{array}$ \\
\hline
\end{tabular}

choosing the narrowest spectrum antibiotic that can be efficient on the identified pathogens is recommended [1].

The misuse of antibiotics has led to an increase in the incidence of antibiotic resistance, becoming a global problem that threatens human health $[18,27,34]$. Since 2014 , WHO has categorized antibiotic resistance as a major threat to public health, with hundreds of thousands of people dying each year from highly resistant bacteria [34].

In the past years, the role of the environment in the appearance of super-bacteria has become more important, representing their main source, but also the main transmission path [30]. However, the knowledge related to this subject is quite limited and automatically, the mechanism of formation of super-resistant bacteria is not fully elucidated [34].

There is a clear cause-and-effect relationship between the exposure to antibiotic treatments and the emergence of antibiotic resistance; the more frequent these treatments are, the higher the risk of resistant infections. In order to minimize this risk, it is mandatory to reduce the prescription of antibiotics when it is not necessary [39]. Another factor that has led to discussions is represented by incomplete treatments, assuming that they conduct to an increase in the incidence of antibiotic-resistant microorganisms a 2016 study entitled "Antibiotic awareness week", the World Health Organisation recommended that patients always complete antibiotic treatments, even if they feel better after a few days; otherwise, there is a risk of developing antibiotic-resistant bacteria, endangering both them and those around them. However, there are no clinical trials to prove this. Thus, various health organizations, such as the US Centre for Disease Control and Prevention (CDC) and Public Health England, replaced the message sent by the WHO, advising patients to take antibiotics "exactly as prescribed by their doctor" [39]. 
TABLE 4. The side effects of antibiotics in pediatric dentistry

\begin{tabular}{|c|c|c|}
\hline Author & Antibiotic & Side effects \\
\hline Shenoy ES et al. (2019) & $\begin{array}{l}\text { Penicillin G } \\
\text { (intramuscular/ } \\
\text { intravenous) and V } \\
\text { (per os) }\end{array}$ & allergic reactions, nausea, vomiting, diarrhoea, fever, rash [29] \\
\hline Zandbergen D et al. (2016) & Amoxicillin & $\begin{array}{l}\text { Nausea, diarrhoea, vomiting and gastrointestinal discomfort, taste } \\
\text { alterations, dizziness, headache, a rash on the neck of the face [40] }\end{array}$ \\
\hline $\begin{array}{c}\text { Gomez R et al. (2012), } \\
\text { Easton J et al. (2003) }\end{array}$ & $\begin{array}{c}\text { Amoxicillin }+ \\
\text { potassium clavulanate }\end{array}$ & $\begin{array}{c}\text { digestive phenomenon (diarrhoea, vomiting, nausea, indigestion), liver } \\
\text { toxicity. A modification of the dose in patients with renal pathologies is } \\
\text { required }[11,34]\end{array}$ \\
\hline Bakheit A et al. (2014) & Azithromycin & $\begin{array}{c}\text { Anorexia, dyspepsia, nausea, diarrhoea, colitis, flatulence, dizziness, } \\
\text { headache, drowsiness, convulsions, arthralgia, and disturbances in taste } \\
\text { and smell, liver dysfunctions, syncope, insomnia, agitation, anxiety, } \\
\text { asthenia, paraesthesia, hyperactivity, thrombocytopenia, haemolytic } \\
\text { anaemia, interstitial nephritis, acute renal failure, photosensitivity, tooth } \\
\text { and tongue discoloration [25] }\end{array}$ \\
\hline Campagna JD et al. (2012) & $\begin{array}{l}\text { Cephalosporins } \\
\text { (Cefuroxime) }\end{array}$ & Rash, urticaria, anaphylaxis, exacerbation of kidney diseases, colitis [31] \\
\hline $\begin{array}{l}\text { Nowak AJ et al. } \\
\text { (2019), } \\
\text { Pouwels KB et al. (2019) }\end{array}$ & Clindamycin & $\begin{array}{l}\text { Severe diarrhoea, colitis, thrombophlebitis, hypotension, } \\
\text { thrombocytopenia. It is associated with a high risk of infection with } \\
\text { Clostridium difficile }[1,41]\end{array}$ \\
\hline $\begin{array}{l}\text { Nowak AJ et al. (2019), } \\
\text { Dar-Odeh N et al. (2018), } \\
\text { Pouwels KB et al. (2019) }\end{array}$ & Fluoroquinolones & $\begin{array}{c}\text { Photosensitivity, low glycemic index, QT prolongation } \\
\text { (cardiac rhythm pathologies), peripheral neuropathy, chondrotoxicity in } \\
\text { the growing bone cartilage }[1,24,41]\end{array}$ \\
\hline $\begin{array}{l}\text { Nowak AJ et al. (2019), } \\
\text { McGowan et al. (2018), } \\
\text { Vicente D et al. (2010) }\end{array}$ & Metronidazole & $\begin{array}{c}\text { Gastrointestinal manifestations (nausea, diarrhoea, pain in the } \\
\text { epigastrium, discomfort), cephalea, glossitis, stomatitis and metallic taste. } \\
\text { When prescribed in patients with hepatic dysfunctions, its metabolites in } \\
\text { the liver are elevated }[1,17,36]\end{array}$ \\
\hline $\begin{array}{l}\text { Goel D et al. } \\
\text { (2020), Becker DE (2011), } \\
\text { Vicente D et al. (2010) }\end{array}$ & Tetracyclin & $\begin{array}{c}\text { nausea, vomiting, stomatitis, glossitis, photosensitivity, liver toxicity, renal } \\
\text { insufficiency }[3,17,37] \text {. Antacids and dairy products lower the intraoral } \\
\text { absorption [38] }\end{array}$ \\
\hline
\end{tabular}

\section{THE IMPORTANCE OF THE IMPLICATION OF BOTH PARENTS AND CHILDREN}

Regarding the compliance of the pedodontic patient, among the strategies listed by Gardiner et al. in order to motivate the child to take the prescribed dose of medication, there are: oral suspensions or various pills / capsules with pleasant taste, different ways to catch their attention or to supervise them (memories, planning, a relationship between doctor and parent) [39].

A well-established plan based on a mutual agreement between the parent and the doctor on the child's medication increases the safety of its correct administration [39].

\section{CONCLUSIONS}

The literature reports are showing that every year there's a growing trend of overuse and with- out therapeutic justification of drugs (especially antibiotics). Amoxicillin is the most frequently prescribed antibiotic, with an indication of administration of 5 days. The misuse of antibiotics has led to an increase in the incidence of antibiotic resistance, becoming a global problem that threatens human health. Choosing the right antibiotic and prescribing it in a conservative and effective way minimizes the potential side effects that can occur. Also, a check-up every 1-2 days can be beneficial to verify the effectiveness of the treatment, but also to detect possible side effects. A correct and well-defined treatment plan, made by mutual agreement between doctor and patient, as well as a good collaboration and communication between them, can be the basis of a well-conducted therapy. 


\section{REFERENCES}

1. Nowak AJ, Christensen JR, Mabry TR, Townsend JA, Wells MH, editors. Pediatric Dentistry: Infancy through adolescence. $6^{\text {th }} \mathrm{ed}$. Elsevier; 2019.

2. Schwartz S. Commonly Prescribed Medications in Pediatric Dentistry Crest $₫$ Oral-B $₫$ at dentalcare.com. Continuing Education Course, Revised January 8, 2016.

3. Goel D, Goel GK, Chaudhary S, Jain D. Antibiotic prescriptions in pediatric dentistry: A review. J Family Med Prim Care. 2020 Feb 28;9(2):473-480

4. Surbhi Leekha, MBBS, Christine L. Terrell, MD, and Randall S. Edson, MD. General Principles of Antimicrobial Therapy. Mayo Clin Proc. 2011 Feb; 86(2):156-167.

5. Mesaros M, Muntean A. Medicină dentară pediatrică. Cluj-Napoca: Editura Medicală Universitară "Iuliu Haţieganu”, 2016:199-207, 254-265.

6. Gafar M, lliescu A. Endodonţie clinică și practică, ediţia a II-a. București: Editura Medicală, 2016.

7. Dar-Odeh NS, Abu-Hammad OA, Al-Omiri MK, Khraisat AS, Shehabi AA. Antibiotic prescribing practices by dentists: a review. Ther Clin Risk Manag. 2010 Jul 21;6:301-6.

8. Aidasani B, Solanki M, et al. Antibiotics: Their Use and Misuse in Paediatric Dentistry. A Systematic Review. Eur J Paediatr Dent. 2019 Jun;20(2):133-138.

9. Dar-Odeh N, Fadel HT, Abu-Hammad S, Abdeljawad R, Abu-Hammad OA. Antibiotic Prescribing for Oro-Facial Infections in the Paediatric Outpatient: A Review. Antibiotics (Basel). 2018 Apr 25;7(2):38.

10. Isla A, Canut A, Gascón AR, Labora A, Ardanza-Trevijano B, Solinís MA, Pedraz JL. Pharmacokinetic/pharmacodynamic evaluation of antimicrobial treatments of orofacial odontogenic infections. Clin Pharmacokinet. 2005;44(3):305-16.

11. Easton J, Noble S, Perry CM. Amoxicillin/clavulanic acid: a review of its use in the management of paediatric patients with acute otitis media. Drugs. 2003;63(3):311-40. 12. Hong L, Levy SM, Warren JJ, Dawson DV, Bergus GR, Wefel JS. Association of amoxicillin use during early childhood with developmental tooth enamel defects. Arch Pediatr Adolesc Med. 2005 Oct;159(10):943-8.

12. American Academy of Pediatric Dentistry. Useful Medications for Oral Conditions, The reference manual of pediatric dentistry, American Academy of Pediatric Dentistry; 2019. Available at: https:// www.aapd.org/globalassets/media/policies_guidelines/r_ usefulmeds.pdf.

13. Skoog Ståhlgren G, Tyrstrup M, Edlund C, Giske CG, Mölstad S, Norman C, Rystedt K, Sundvall PD, Hedin K. Penicillin V four times daily for five days versus three times daily for 10 days in patients with pharyngotonsillitis caused by group A streptococci: randomised controlled, open label, non-inferiority study. BMJ. 2019 Oct 4;367:15337.

14. Wilcox MH, Chalmers JD, Nord CE, Freeman J, Bouza E. Role of cephalosporins in the era of Clostridium difficile infection. J Antimicrob Chemother. 2017 Jan;72(1):1-18.

15. McFarland LV, Ozen M, Dinleyici EC, Goh S. Comparison of pediatric and adult antibiotic-associated diarrhea and Clostridium difficile infections. World J Gastroenterol. 2016;22(11):3078-3104.

16. Vicente D, Pérez-Trallero E. Tetraciclinas, sulfamidas y metronidazol. Enfermedades Infecciosas y Microbiología Clínica. 2010;28(2):122-130.

17. Cherry WR, Lee JY, Shugars DA, White RP Jr, Vann WF Jr. Antibiotic use for treating dental infections in children: a survey of dentists' prescribing practices. J Am Dent Assoc. 2012 Jan;143(1):31-8.

18. National Institute for Health and Care Excellence (NICE). Public Health England. Summary of antimicrobial prescribing guidance managing common infections, 2020. Available at: https://www.nice. org.uk/about/what-we-do/our-programmes/nice-guidance/ antimicrobial-prescribing-guidelines.

19. Bucur A. Compendiu de chirurgie oro-maxilo-facială, volumul I. Bucureşti: Med Publishing, 2010.
20. Council O, Guideline on Use of Antibiotic Therapy for Pediatric Dental Patients, Reference Manual v. 32/No 6, 10/11. Latest revision: 2019. Available at: https://www.aapd.org/assets/1/7/G_ Antibiotictherapy.pdf.

21. Bragg L, Alvarez A. Endocarditis. Pediatrics in Review. 2014;35(4):162-168.

22. Aidasani B, Solanki M, et al. Antibiotics: Their Use and Misuse in Paediatric Dentistry. A Systematic Review. Eur J Paediatr Dent. 2019 Jun;20(2):133-138

23. Dar-Odeh N, Fadel HT, Abu-Hammad S, Abdeljawad R, AbuHammad OA. Antibiotic Prescribing for Oro-Facial Infections in the Paediatric Outpatient: A Review. Antibiotics (Basel). 2018 Apr 25;7(2):38.

24. Bakheit AH, Al-Hadiya BM, Abd-Elgalil AA. Azithromycin. Profiles Drug Subst Excip Relat Methodol. 2014;39:1-40.

25. Smith MJ, Gonzalez D, Goldman JL, et al. Pharmacokinetics of Clindamycin in Obese and Nonobese Children. Antimicrob Agents Chemother. 2017;61(4):e02014-16.

26. Cope AL, Francis NA, Wood F, Chestnutt IG. Antibiotic prescribing in UK general dental practice: A cross-sectional study. Community Dent Oral Epidemiol. 2016;44:145-53.

27. Klein EY, Van Boeckel TP, Martinez EM, et al. Global increase and geographic convergence in antibiotic consumption between 2000 and 2015. Proc Natl Acad Sci U SA. 2018 Apr 10;115(15): E3463-E3470.

28. Shenoy ES, Macy E, Rowe T, Blumenthal KG. Evaluation and Management of Penicillin Allergy: A Review. JAMA. 2019 Jan 15;321(2):188-199.

29. Abrams EM, Ben-Shoshan M. Should testing be initiated prior to amoxicillin challenge in children? Clin Exp Allergy. 2019 Aug;49(8):1060-1066.

30. Campagna JD, Bond MC, Schabelman E, Hayes BD. The use of cephalosporins in penicillin-allergic patients: a literature review. J Emerg Med. 2012 May;42(5):612-20.

31. Fjeld $H$, Raknes $G$. Is combining metronidazole and alcohol really hazardous?. Tidsskr Nor Laegeforen. 2014 Sep 16;134(17):1661-3.

32. Bengtsson-Palme J, Kristiansson E, Larsson DGJ. Environmental factors influencing the development and spread of antibiotic resistance. FEMS Microbiol Rev. 2018 Jan;42(1):fux053.

33. Gomez R, Fernandez S, Aspirot A, Punati J, Skaggs B, Mousa H, Di Lorenzo C. Effect of amoxicillin/clavulanate on gastrointestinal motility in children. J Pediatr Gastroenterol Nutr. 2012 Jun; 54(6):780-4.

34. Pouwels KB, Hopkins S, Llewelyn MJ, Walker AS, McNulty CA, Robotham JV. Duration of antibiotic treatment for common infections in English primary care: cross sectional analysis and comparison with guidelines. BMJ. 2019 Feb 27;364:1440.

35. McGowan K, McGowan T, Ivanovski S. Optimal dose and duration of amoxicillin-plus-metronidazole as an adjunct to non-surgical periodontal therapy: A systematic review and meta-analysis of randomized, placebo-controlled trials. J Clin Periodontol. 2018 Jan; 45(1):56-67.

36. Becker DE. Adverse drug interactions. Anesth Prog. 2011 Spring; 58(1):31-41.

37. Smieszek T, Pouwels KB, Dolk FCK, Smith DRM, et al. Potential for reducing inappropriate antibiotic prescribing in English primary care. J Antimicrob Chemother. 2018 Feb 1;73(suppl_2):ii36-ii43.

38. Gardiner P, Dvorkin L. Promoting medication adherence in children. Am Fam Physician. 2006 Sep 1;74(5):793-8.

39. Zandbergen D, Slot DE, Niederman R, Van der Weijden FA. The concomitant administration of systemic amoxicillin and metronidazole compared to scaling and root planing alone in treating periodontitis: a systematic review. BMC Oral Health. 2016 Feb 29;16:27.

40. Pouwels KB, Hopkins S, Llewelyn MJ, Walker AS, McNulty CA, Robotham JV. Duration of antibiotic treatment for common infections in English primary care: cross sectional analysis and comparison with guidelines. BMJ. 2019 Feb 27;364:1440. 